Variations in Sediment Sources and Yields in the Finger Lakes

and Catskills Regions of New York

PUBLISHED IN HYDROLOGICAL PROCESSES Vol 21 828-838. 2007

Gregory N. Nagle*\#, Timothy J. Fahey* Jerry C. Ritchie**, and Peter B. Woodbury***

*Cornell University, Department of Natural Resources, Fernow Hall, Ithaca NY 14853.

\#Corresponding author, email gnagle2000@yahoo.com,.

** USDA, Agricultural Research Service. Hydrology and Remote Sensing Laboratory, BARC-

West, Bldg 007, Beltsville, MD. 20705

***Cornell University, Department of Crop and Soil Sciences, Emerson Hall, Ithaca NY 14853. 


\title{
Variations in Sediment Sources and Yields in the Finger Lakes and Catskills Regions of New York
}

\begin{abstract}
The proportional contributions of stream bank and surface sources to fine sediment loads in watersheds in New York State were quantified with uncertainty analysis. Eroding streamside glacial drift, including glaciolacustrine deposits, were examined to help explain variations in the proportional contributions made by bank erosion. Sediment sources were quantified by comparing concentrations of the bomb-derived radionuclide ${ }^{137} \mathrm{Cs}$ in fluvial sediment with sediment from potential source areas such as agricultural soils, forest soils and stream banks.

To compare sediment sources in streams where deposits of fine-grained glacial drift were abundant with watersheds that lacked moderate or extensive streamside deposits, samples were taken from fifteen watersheds in the region. The mean contribution of bank erosion to sediment loads in the six streams with glaciolacustrine deposits was 60\% (range 46 to 76\%). The proportional contribution of bank erosion was also important in one stream lacking glaciolacustrine deposits (57\%) but was less important in the remainder with contributions ranging from 0 to $46 \%$. Data from this study on the varying contributions of bank erosion and data from past studies of sediment yield in fifteen watersheds of New York State suggest that eroding streamside glacial deposits dominate sediment yield in many watersheds. In other watersheds, past impacts to streams such as channelization have also resulted in high levels of bank erosion.
\end{abstract}

Key words: Bank erosion, sediment sources, tracers, New York State, ${ }^{137}$ Cs.

\section{Introduction}


Eroding channel banks are thought to be a major source of sediment in some regions of the U.S. (USDA-SCS, 1975) although there have been only a few attempts to quantify this source (Brigham et al., 2001; Glasmann, 1997; Nagle and Ritchie, 1999; Nagle and Ritchie, 2004; Odgaard, 1987; Sekely et al., 2002). In drainages with a large capacity to store sediment, much of the stream sediment may be from eroding banks in riparian areas or gullies (Olley et al., 1993; Wallbrink et al.,1996). It was estimated that more than $50 \%$ of the annual sediment yield of Illinois streams comes from bank and bed erosion (National Research Council, 1992).

High rates of bank erosion in northern North America also appear to be associated with glacial geology in some locations For example, Ashmore (1993) concluded that in most of Canada, stream and near- stream valley sides are the dominant sediment sources, a legacy of glaciation that left large quantities of readily erodible fine sediment in the landscape. Gordon (1979) estimated that the vast portion of the sediment moved by the Connecticut River over the last 8000 years was from erosion of glacial lake deposits, a pattern that continued even as much of the hillside land was cleared for agriculture by Euro-American settlers. Sekely et al. (2002) estimated that between 31 and $44 \%$ of the total annual suspended sediment load in the Blue Earth River of Minnesota was from slumping of streamside glacial drift deposits.

The objective of the present study was to quantify the proportional contributions of surface and bank erosion to sediment yield in streams of the southern Cayuga Lake basin and nearby watersheds in New York State, interpret our findings in relation to the wider literature on sediment sources and yields in our study region, and to find evidence that clearing and land use changes in the early to mid 19th century might still be impacting sediment yields in central New York watersheds. 


\section{Study Area}

Cayuga Lake is located in the Glaciated Allegheny Plateau physiographic province (Fenneman, 1938) in central New York State (Figure 1). The southern basin of Cayuga Lake is included on New York State’s Priority Water Bodies List with sediment listed as the primary pollutant (Genesee/Finger Lakes Regional Planning Council 2001). A field survey of 1200 sites indicated stream bank erosion as a serious sediment source problem in parts of the southern Cayuga basin (Cayuga Lake Watershed Intermunicipal Organization, 2000).

Cayuga Lake is in a glacial valley with a watershed encompassing $2041 \mathrm{~km}^{2}$. Annual precipitation at Ithaca NY averages $80 \mathrm{~cm}$, evenly distributed throughout the year. The altitude of the lake is $116 \mathrm{~m}$ above sea level. The watershed is characterized by low relief in its northern portion and higher elevations and steeper slopes in the southern portion. The upland plateau is at an elevation of 249-298 $\mathrm{m}$ with hills extending to about $600 \mathrm{~m}$. The land cover in this southern portion is principally forested upland or forested wetland. Surficial geology of the majority of the Cayuga Lake watershed consists of till of variable texture and thickness. Most soils in the watershed formed in different types of deposits resulting from glaciation. Glacial till is the most extensive source of parent material, but other less extensive parent materials in the watershed include glaciolacustrine sediments and glaciofluvial (outwash) deposits.

The Catskills mountain region (Figure 1) is surrounded by the glaciated Allegheny Plateau except on the east side where it borders the Hudson Valley physiographic province (Fenneman, 1938). The Catskills rise higher than the neighboring plateau and although structurally a part of it, constitute a distinct geological unit. The fact that the highest mountains rise about 600 meters above the adjacent parts of the Allegheny plateau seems to be due to the superior resistance of the coarse textured rocks of 
which they are composed. (Rich 1934). Glacial deposits in the Catskills basin are primarily till and outwash with minimal areas of proglacial lacustrine deposits (Cadwell, 1986).

The Catskills study watersheds ranged in elevation from 350 to 1200 meters. Forests cover about $75 \%$ of the area. Lower hill slopes and valley bottoms were cleared for agriculture and pasture in the $19^{\text {th }}$ century but most hill slope land has since reverted to forest and row crop agriculture is now concentrated in main valley bottoms though much hill land is still in pasture. The Catskills region is the principal contributor to the New York City water supply system. A pressing water quality concern is the supply of sediment to the reservoirs. In addition to impacts on water clarity, sediment is the principal vector carrying phosphorus to reservoirs (National Research Council, 2000).

\section{Methods}

\section{Background: Sediment tracers}

Sediment provenance can be determined by comparing the properties of samples collected from streams with potential source areas such as agricultural soils, forests and channel banks. There have been a number of methods used to fingerprint source areas of fluvial sediment. These include particulate phosphorus (Hasholt, 1988), mineral magnetic measurements (Slattery et al., 1995), the identification of clay minerals (Glasman, 1997; Youngberg and Klingeman, 1971), and sediment carbon and nitrogen (Peart and Walling, 1988,1986; Walling and Bradley, 1990; Walling et al., 1993; Collins et al., 1997). The use of mixing models to identify the relative contribution of different sources has been demonstrated and examined in detail in the literature (Foster and Lees, 2000). Successful use of bombderived and natural radionuclides in sediment tracer work has been reported in Poland (Froehlich and Walling 1997), Australia (Olley et al., 1993; Wallbrink et al., 1996; Wallbrink et al., 1998), the US 
Midwest (Brigham et al., 2001, Matisoff et al., 2002) and the U.S. Northwest (Nagle and Ritchie, 1999 2004).

In this study the nuclear bomb-derived radionuclide ${ }^{137}$ Cs was used as a tracer to quantify the sources of fluvial sediment in the study streams. Atmospheric nuclear tests in the 1950's and early 1960’s distributed radioactive fallout ${ }^{137}$ Cs around the globe. Cesium-137 was deposited in precipitation and adsorbed by soil where much of it still remains (half-life is 30.17 years). Fallout levels peaked in 1963 and with the ban on atmospheric tests, subsequently declined to minimal levels.

Atmospheric-borne radionuclides accumulate near the soil surface, with ${ }^{137}$ Cs concentrated within 30 cm of the surface (Wallbrink and Murray, 1996). General source areas of sediment can be identified based on variations in concentrations of bomb-fallout and natural radionuclides. This tracer method is effective for distinguishing surface-derived sediment from sheet and shallow rill erosion and sediment from gullies and stream channel walls because channel and gully walls deeper than $30 \mathrm{~cm}$ usually

contain little or no ${ }^{137} \mathrm{Cs}$. By comparing ${ }^{137} \mathrm{Cs}$ concentrations in stream sediment with concentrations in surface soils and channel banks, a simple mixing model (Wallbrink et al., 1996) can be used to quantify the proportion of stream sediment derived from surface or bank sources. Walling ( 2004) reported the effective use of a simple mixing model using just Cs-137 to distinguish between sediment from surface sources and gullies. Other authors have also reported the use of simple mixing models for distinguishing between bank/gully walls and surface sources of sediments ( Brigham et al 2001, Wallbrink et al 1998, Zhang et al 1995 and 1997).

\section{Field sampling}

New York State surficial geologic maps (Cadwell, 1986), maps of locations of severe bank erosion in the southern Cayuga Basin compiled by a local agency (Cayuga Lake Watershed Intermunicipal 
Organization, 2000) and extensive field reconnaissance were used to identify the location and relative extent of streamside glaciolacustrine deposits and areas of bank erosion in the study watersheds. Actively eroding banks were identified in the field by recently exposed roots and sediment deposits at their base. Banks with herbaceous, grassy or woody vegetation were considered not to be actively eroding. Stream sediment samples were collected from a total of 81 locations distributed along six tributary streams in the southern Cayuga Lake basin. Thirty three samples were also collected from nine other watersheds in the Finger Lakes and Catskills regions where glaciolacustrine deposits were not prominent. Samples were taken where public access was possible and recent fine sediment deposition was obvious. These included Cornell University lands, New York State forest lands, fishing access sites and near road bridges. In some watersheds, such locations with recent fine sediment deposition were difficult to find and therefore fewer samples were collected.

Sediment samples were taken from the top $4 \mathrm{~cm}$ of recent overbank deposits immediately adjacent to the active channels, recent backwater deposits, deposits behind five dams in three streams, and four beaver impoundments in three streams. Samples were taken along the length of the streams and in some first and second order tributaries in order to examine variability in sediment sources from the headwaters to the mouths of the watersheds. Extensive field reconnaissance indicated that in many watersheds, the largest, eroding bank deposits were most often concentrated in the lower reaches of the watersheds and in wider valley positions along third and fourth order channels.

Six Mile Creek was examined the most intensively of all study streams (30 samples) because it is the primary water source for the City of Ithaca, New York and sediment is of the most immediate concern. For the purpose of determining the overall percentages of bank and surface derived sediment for the entire Six Mile Creek watershed, only those stream samples taken in the lower fourth order channel were used in the analysis since they incorporate sediment from a larger area of the watershed. Additional samples in the upper headwater areas of Six Mile Creek were collected in first and second 
order tributaries to examine variations in sediment sources in small areas. The headwaters of Fall Creek were sampled intensively to examine variability in sediment sources but, again, only those samples taken from the lower fourth order channel were used in the analysis of total contribution of bank erosion.

Some other studies of sediment tracers have used pumps to obtain large water samples from which suspended sediment was separated by a centrifuge. Symader and Strunk (1992) described some of the difficulties with the use of suspended sediment to identify source areas. Two of the principal problems are the enrichment of suspended sediment in fines and in organic matter relative to the sources and the transformation of sediment properties within the fluvial system. Recently published work on the use of tracers contend that the use of recent overbank deposits enable the contributions of sediment sources to be identified more reliably and the long-term loading from individual sources to be assessed (Bottrill et al., 2000). Therefore, the data collected for this study on overbank sediment should be compared with caution to data on suspended sediment. To determine whether concentrations in flocculated suspended sediments were similar to those obtained in floodplain samples, three samples were also taken from sediment settling ponds at water treatment plants located in the lower watersheds of two creeks in the Cayuga Lake basin to determine whether concentrations in suspended sediments were similar to those obtained in floodplain samples.

Bank samples were collected by scraping several centimeters in the mid portion of 26 large, actively eroding banks ranging from $1.5 \mathrm{~m}$ to $20 \mathrm{~m}$ in height. To characterize surface soils, 184 samples were collected from 23 sites distributed around the watersheds using a $5 \mathrm{~cm}$ diameter corer to a depth of $10 \mathrm{~cm}$. To accommodate local spatial variability, each surface sample consisted of eight cores taken at least $3 \mathrm{~m}$ apart and composited for analysis. The surface sites that were separately characterized for radionuclide concentrations included 13 samples from currently cropped agricultural fields, 5 from pastures, and 5 from forested areas. 


\section{Laboratory analysis}

To minimize the influence of differences in particle size composition between source materials and channel sediment on the values of the fingerprint properties, all measurements of ${ }^{137}$ Cs were undertaken on the $<63 \mu \mathrm{m}$ fraction. The samples were dried, lightly ground and sieved to separate out the $<63 \mu \mathrm{m}$ fraction. The samples were analyzed for ${ }^{137}$ Cs concentrations at the USDA-Agricultural Research Service Hydrology and Remote Sensing Laboratory in Beltsville, MD. Gamma-ray analyses were performed using the Canberra-2000 Genie-2000 Spectroscopy System. The system is calibrated and efficiency determined using an analytic mixed radionuclide standard (10 nuclides), the calibration of which can be traced to US National Institute of Standards and Technology. The count time for each sample was 30,000 seconds, providing a measurement precision of \pm 4 to $5 \%$ on samples.

\section{Data analysis}

To quantify the relative contributions of bank and cultivated surface sediment sources, data on ${ }^{137}$ Cs concentration were analyzed with a mixing model. This approach has been used effectively both with multiple tracers and with Cs-137 alone to distinguish between sediment from surface sources and gullies. Other authors have also used simple mixing models for distinguishing between bank/gully walls and surface sources of sediments (Brigham et al 2001, Wallbrink et al 1998, Zhang et al. 1995 and 1997). The model is shown in Equation 1 (Wallbrink et al., 1996).

$$
\begin{aligned}
\mathrm{C}_{\mathrm{S}}= & \underline{\mathrm{P}_{\underline{r}}-\underline{\mathrm{P}}_{-}} \times \underline{-}_{-} \times 100 \\
& \mathrm{PS}_{\mathrm{S}}-\mathrm{Pb}
\end{aligned}
$$




\section{Where:}

$\mathrm{C}_{\mathrm{S}}=$ contribution from cultivated surface sources (\%),

$\mathrm{P}_{\mathrm{r}}=$ value of ${ }^{137} \mathrm{Cs}$ for stream sediment,

$\mathrm{P}_{\mathrm{S}}=$ value of ${ }^{137} \mathrm{Cs}$ for cultivated soil,

and $\mathrm{Pb}_{\mathrm{b}}=$ value of ${ }^{137} \mathrm{Cs}$ for bank material.

To account for uncertainty in the mixing model, we used quantitative uncertainty analysis, specifically a Monte Carlo approach. In this approach, model parameters are represented not as single values, such as the mean, but rather as statistical distributions of values. Samples are taken from these distributions and used in the model, and this process is repeated thousands of times to produce a large number of predicted values (Morgan and Henrion, 1990). The $50^{\text {th }}$ percentile of this distribution of values of Cs represents the median prediction, and other quantiles can be used as measures of dispersion of the predicted value.

For our analysis, distribution functions were fit to sample data for each of the parameters in Equation 1, and then values were selected from each distribution using Latin Hypercube sampling using @Risk and BestFit software (Version: Professional 4.5, Palisade Corporation, Ithaca, NY). The parameters were assumed to be independent of each other, and surface soil contributions to stream sediment were assumed to come from cultivated land, not forest or pasture land. Separate analyses were conducted for each stream, and 100,000 iterations were performed for each analysis to produce numerically stable results. The result of the quantitative uncertainty analysis for each stream is the percentage of sediment from stream banks versus cultivated land represented as a distribution of predicted values (Equation 1). For most streams, we present 3 percentiles of this distribution, the $20^{\text {th }}, 50^{\text {th }}$, and $80^{\text {th }}$. However, some streams had 3 or fewer stream sediment samples, and for these streams we present only the 50th 
percentile as a predicted value. Bank samples were not available for all of the streams and for these streams we used a distribution fit to the data for all bank samples. Similarly, a single distribution function was fit to samples from cultivated land and this distribution was used in analyses for each stream.

\section{Results}

Mean levels of ${ }^{137}$ Cs were much lower for bank samples than for surface samples $(\mathrm{P}<0.05)$ (Tables 1 and 2). The low levels of ${ }^{137} \mathrm{Cs}$ in the bank samples was expected because the surfaces of most actively eroding banks were not exposed to atomic bomb fallout during the highest fallout years around 1960. Out of 26 bank samples, only 5 had detectable ${ }^{137}$ Cs present. Mean levels of ${ }^{137}$ Cs were much higher $(\mathrm{P}<0.05)$ for forest soil $\left(24.1 \mathrm{mBq} \mathrm{g}^{-1}\right)$ and pastures $\left(23.7 \mathrm{mBq} \mathrm{g}^{-1}\right)$ than cultivated lands $(11.5$ $\mathrm{mBq} \mathrm{g}^{-1}$ ), while no difference was observed between forests and pastures, indicating that little or no soil has been eroded or moved on pastures since the peak fallout period in 1963 . Levels of ${ }^{137}$ Cs on cultivated lands also showed the typical high variability $\left(7.7-16.36 \mathrm{mBq} \mathrm{g}^{-1}\right)$ that results from the mixing of ${ }^{137}$ Cs -rich surface layers by cultivation and the erosion of soil from upper slopes and subsequent deposition on lower slopes (Nagle et al., 2000, Nagle and Ritchie 2004). The results from the three water treatment settling pond samples from two streams were similar to those from the lower watershed stream samples; the mean for these samples was $2.2 \mathrm{mBq} \mathrm{g}^{-1}$ (range: 1.76-2.65).

Based on the results of the mixing model, the most likely contribution of bank erosion to sediment loads in the six Cayuga watersheds ranged from 8 to $76 \%$ with a mean of $54 \%$ (Table 2). Based on the quantitative uncertainty analysis, these estimates are more precise for some streams than others (Figure 2) . For example, for Fall Creek in the Cayuga Basin, there is a $20 \%$ chance that the contribution of 
banks was as low as $9 \%$ or as high as $84 \%$ (Table 2). However, for Wright Creek in the Catskills, this range was only 0 to $9 \%$.

Although these data indicate that stream banks were the dominant sediment source overall in the southern Cayuga basin, ${ }^{137}$ Cs concentrations in sediment samples were much higher in the headwaters of the Six Mile Creek watershed, indicating that surface erosion is the dominant sediment source in forested headwater streams with few eroding banks. Samples from Six Mile Creek, the most intensively sampled stream (30 samples including the forested headwater reaches), showed ${ }^{137}$ Cs concentrations ranging from 0 to $43 \mathrm{mBq} \mathrm{g}^{-1}$, with much higher mean values found in the headwaters (13.9 mBq g${ }^{-1}$ ) than in the lower watershed $\left(2.7 \mathrm{mBq} \mathrm{g}^{-1}\right)$. The highest levels were found in samples from first order streams flowing through forested lands in the steep headwaters indicating surface soil eroded from the top few centimeters where the ${ }^{137} \mathrm{Cs}$ had not been diluted by mixing from cultivation. Similarly, the upper reaches of Fall Creek were dominated by surface sources with high ${ }^{137}$ Cs concentration values (17.9 $\left.\mathrm{mBq} \mathrm{g}^{-1}\right)$. Upper Fall Creek has some of the highest concentrations of crop land in the basin. Samples from the upper third of Virgil Creek $\left(8.3 \mathrm{mBq} \mathrm{g}^{-1}\right)$ also indicated the dominance of surface sediment sources from cultivated lands in the more intensively cropped upper valley. Field reconnaissance indicated that both upper Virgil and Fall Creeks lack the large eroding streambanks characteristic of their mid and lower reaches.

Samples collected from most other floodplain sites in regional watersheds indicated proportionally lower contributions of bank erosion (Table 2) compared with most streams in the southern Cayuga basin. Given similar rainfall levels, it can be assumed that ${ }^{137}$ Cs concentrations in surface soils are similar to those for the Cayuga streams. Bank sediment sources appear to be much less important in streams in the region lacking extensive eroding streamside glaciolacustrine and glacial drift deposits (Table 2) characteristic of some streams in the southern Cayuga basin. For example, the results for 
Trout Creek and the West Branch of the Delaware River indicate that bank erosion accounted for little or none of the fluvial sediment in these streams. In contrast to this pattern of lower bank erosion in the sandstone dominated western Catskills, sampling the northern Catskills in the Schoharie River drainage which is primarily shale bedrock, indicated relatively high bank erosion in the Westkill and Batavia Kill drainages (56 and 46\% bank sources respectively, Table 2). Even though the available maps do not show that fine grained glaciolacustine deposits are prominent, field observations indicate their importance.

In tracer studies there are several potential sources of uncertainty in the estimates of sediment sources. We have addressed important uncertainties by using quantitative uncertainty analysis. As expected, when fewer samples are collected, or there is much variation among samples from the same source area, there is more uncertainty in predictions of the amount of sediment from banks versus cultivated lands (Table 2). However, not all potential sources of uncertainty were included in our model. One such issue is the influence of particle size differences between source and channel sediments. No analysis of particle sizes was performed in this study but as has been standard procedure in tracer studies, all samples were sieved to separate out the $<63 \mu \mathrm{m}$ fraction (silts and clays) for analysis. Also, by using overbank samples from flood plains, we avoided the problems with particle size enrichment that can occur when using suspended sediment.

Variability among samples from cultivated soils is common, and results from variation in cultivation, soil erosion and re-deposition. Variability among bank samples is also common, because most bank samples have no ${ }^{137} \mathrm{Cs}$, so even a few samples with measurable counts results in variability (Nagle and Ritchie 1999). Despite these necessary reflections on uncertainty in these estimates, the analysis demonstrates clear differences in the percentage of stream sediment that can be attributed to bank erosion among many of the 15 study streams. 


\section{Discussion}

\section{Sediment sources in regional watersheds}

The long term decline in agriculture, abandonment of steeper cultivated land, and changes in agricultural practices have resulted in greatly reduced runoff and erosion from croplands across parts of the U.S. (Trimble and Crosson, 2000) including the Northeast (Whitney, 1994); hence, many rural watersheds in central New York appear to be in better condition than they were historically. However analysis of radionuclides in lake cores (discussed below) indicate that sediment loads in the southern Cayuga basin do not appear to have declined in recent decades with changes in land use. More recent impacts include road building and suburban housing developments which often result in large, shortterm increases in sediment and increased runoff from paved areas (Leopold, 1994). Bank erosion also may have accelerated in places, especially in those streams which were extensively channelized after the 1930s.

Yager (2001) used radionuclides to analyze nine sediment cores from Cayuga Lake and found presettlement sediment accumulation rates of less than $1 \mathrm{~mm} \mathrm{yr}^{-1}$ based on radiocarbon dates for wood fragments found in two cores. Sedimentation rates of 2.4 to $6 \mathrm{~mm} \mathrm{yr}^{-1}$ since 1900 were computed with

${ }^{210} \mathrm{~Pb}$ from six cores. Since the mid-20th century, sedimentation rates have remained high, with rates of 2.4 to $8.1 \mathrm{~mm} \mathrm{yr}^{-1}$ since the 1950 's computed from the maximum depth of ${ }^{137}$ Cs penetration in nine cores. With the reversion of hillside crop lands to forest and likely decline in agricultural erosion across most of the Cayuga watershed, the continuing high sediment yields apparently result from continuing high levels of bank erosion. Studies from the other regions suggest that much of the current stream sediment represents eroded agricultural soil from the 19th century (Nagle and Ritchie, 2004, Trimble 1983; Phillips 1991). 
In glaciated regions of the Northeast, differences among watersheds in the amount of eroded sediment caused by bank erosion may be determined in part by the presence of streamside glacial drift deposits, and in particular, the predominance of fine-grained glaciolacustrine deposits. Bent (2000) reported that in the Housatonic basin in New England, the occurrence of stratified drift deposits was highly correlated with suspended sediment yields for eight subbasins; the effect of these deposits on sediment yields was thought to be greater where they were glaciolacustine deposits. Stone and Sauderson (1996) found that the highest sediment yields were found in Canadian subbasins with agricultural and industrial development on fine grained glaciolacustrine materials. Similarly, Crosby and Deboer (1995) noted the dominant contribution of glaciofluvial and glaciolacustrine deposits in main valley floors to suspended sediment loads in the Assiniboine-White River system.

\section{Regional observations of sediment yield}

Bank erosion is an important sediment contributor in most of the tributaries of the southern Cayuga basin although data indicate that suspended sediment production is not high in comparison with the average regional sediment yield estimate of 90 tons $\mathrm{km}^{-2} \mathrm{yr}^{-1}$ for the Northeast (Leopold 1994; Table 3). However, large variations in overall sediment yield in different tributaries might be attributed to varying contributions from bank erosion. For example, measurements on two major tributaries of Fall Creek (Fig. 2 ) in the early 1970s (D.R. Bouldin, unpublished data) indicated much higher sediment yields from Virgil Creek (57 tons $\mathrm{km}^{-2} \mathrm{yr}^{-1}$ ) than from Upper Fall Creek (23 tons $\mathrm{km}^{-2} \mathrm{yr}^{-1}$ ), probably owing to contrasts between the channels of these streams. Upper Fall Creek has extensive valley bottom wetlands, a densely vegetated floodplain area and active beaver dams that capture much eroded sediment. Except for a few places where the stream was channelized in the past, large stream cut banks are uncommon. In contrast, as Virgil Creek flows below the Allegheny escarpment, it passes through an area of glaciolacustrine and unstable glacial drift deposits that are undermined as the stream cuts into the 
toe of the steep slope. Virgil Creek also has direct input of sediment from long stretches of eroding banks in its lower valley. Aerial photos indicate that since 1938, parts of the lower stream were rerouted and channelized.

Strong support for the hypothesis that glacial drift is a primary source of sediment in the Glaciated Allegheny Plateau physiographic region can also be found in the results from the a study in the Genesee River basin that was the most intensive effort to measure sediment yields in New York State (EPA, 1991). Sediment yields in parts of the Genesee basin are as high as 204 tons $\mathrm{km}^{-2} \mathrm{yr}^{-1}$ (Table 3), among the highest sediment yields in the Northeast, and largely associated with glacial deposits.

A USGS Susquehanna River basin study also notes that some of the highest sediment yields are from the glaciated section of the basin and major variations in yields appear to be associated with finegrained glacial deposits (Williams and Reed, 1972). Sediment yields in the eastern part of the N.Y. Susquehanna basin are generally much lower than those in the western portion (Table 3), likely because of the coarser sandstone bedrock in the east and relatively fewer deposits of fine-grained glacial drift. In much of the Catskills, an area lacking large areas of eroding glacial drift deposits, the relatively low sediment yields of 24 tons $\mathrm{km}^{-2} \mathrm{yr}^{-1}$ for the West Branch of the Delaware (Table 3) also suggest the likely influence of glacial deposits on sediment yields.

Evidence from our study also points towards the importance of glacial deposits as important sources of high bank erosion in parts of central New York. In particular, several of the watersheds with especially high proportion of sediment contributed by bank erosion (Table 2) are those with extensive glaciolacustrine deposits. For example, the lower section of Six Mile Creek has some of the most extensive and deepest glaciolacustrine deposits in this region (Cadwell, 1986; Karig et al., 1995). Many stretches of the lower stream are characterized by slumping hillslopes and large eroding banks along the channel. Even forested slopes with minimal human impact exhibit this instability. Suspended sediment 
yields in this creek were 104 and 133 tons $\mathrm{km}^{-2} \mathrm{yr}^{-1}$ for 2000 and 2001 respectively (USGS 2001, 2002)

(Table 3). Although these values are not unusually high in comparison with the regional average, this short period of record does not coincide with any major flood events that would inflate the long term estimates. Karig (2001), citing reservoir sedimentation estimates made prior to 1978, estimated a longer term average sediment yield of 197 tons $\mathrm{km}^{-2} \mathrm{yr}^{-1}$ for Six Mile Creek including bedload. Conversely, in catchments with much smaller areas of mapped glacial drift deposits in the Catskills, both lower proportional contribution of bank erosion and low sediment yields (Table 2) support the hypothesis that glacial drift plays a dominant role in regional sediment yields (Table 3).

Our data also revealed some clear exceptions to the general pattern that differences among streams in bank erosion are explained by glacial drift deposits. For example, although surface geology maps of Salmon Creek in the southern Cayuga basin do not show extensive glaciolacustrine deposits, bank erosion still contributed an estimated $57 \%$ of the sediment load.

One of the problems with interpreting the impacts of glacial deposits is that they are not mapped comprehensively on many soil surveys or geological maps. Large eroding glacial deposits such as those found along Fall Creek and along the lower part of Salmon Creek are not usually noted on standard soil survey or geological maps. Many of the eroding banks on Fall Creek are also not "glaciolacustrine" but varied glacial drift deposits that buried the ancient channel of Fall Creek and are now eroding. Much of the extensive glaciolacustrine deposits exposed by erosion in lower Six Mile Creek are not indicated on the New York State Surficial Geologic Map (Cadwell, 1986), since these buried deposits are not present on the surface. The longest stretches of eroding banks along Cayuga Inlet are alluvial, not glacial drift deposits.

\section{The role of stream channel changes in bank erosion}


The predominance of stream bank sediment sources in the southern Cayuga Lake basin raises questions about how changes in stream channels have increased bank erosion. Erosion of glacial deposits and other stream bank material was likely increased by human impacts on stream channels since Euro-American settlement. These processes have played out in varying ways in different watersheds in this region. A lingering impact of historical upland erosion is high levels of bank erosion in response to changes in stream channel morphology. Historically, dense riparian vegetation probably protected many stream banks and spread flood flows, stabilizing alluvial sediment. Direct postsettlement impacts on stream channels included sediment eroded from hillsides, increased peak flows resulting from forest clearing and urbanization, the elimination of beavers, trampling by livestock, and impacts from agricultural development.

Sediment yields were increased by higher runoff from cleared hillsides and accelerated erosion of unstable glacial outwash deposits may have increased the amount of bedload moving through the channels, resulting in wider channels and increased pressure on banks. Based on the examination of the bankfull dimensions of abandoned stream channels, Fitzpatrick et al. (1999) estimated that volumes of bankfull flows in North Fish Creek, Wisconsin increased three-fold after agricultural clearing in the late 19th century. Knox (1977) estimated a similar three- to five-fold increase in bankfull flows in other Wisconsin streams. Channels of some presettlement Wisconsin streams also apparently had cross sectional forms that differed dramatically from present day channels. The impact of agricultural land use caused some headwater channels to widen greatly. Transportation and deposition of bedload sediment accompanied by bank erosion was a principal cause of channel widening. Channel migrations and lateral accretions of sediments were greatest where downstream reductions in channel gradient concentrated the deposition of bedload sediments (Knox 1977).

Another response in some streams to the increase in peak flows was channel incision. As these channels eventually reduced their slopes, bank cutting was accelerated as channels reestablished their 
meanders. With the adoption of soil conservation measures and reversion of much marginal agricultural land to forest, these flood peaks have decreased but impacts on stream channels and bank cutting have often persisted (Fitzpatrick et al., 1999).

Sediment eroded from agricultural lands in the early to mid 19th century and stored as alluvial deposits in the watersheds has continued to be a major source of sediment in many drainages in the upper Midwest (Trimble, 1983) and the Southeast (Phillips, 1991). Indeed, on the basis of seven ${ }^{14} \mathrm{C}$ dated samples of buried wood from four streams in the Cayuga basin (unpublished data), we observed that in many places streams are now cutting through post-settlement alluvial deposits. However, in several locations streams have also incised into older alluvial material predating Euro-American settlement. These incised channels are likely due to a combination of factors including increased peak flows after agricultural clearing, deliberate channelization in some locations, the elimination of beaver 200 years ago (Dobyns, 1981; Parker et al., 1985), and channel changes as streams pushed out postsettlement alluvium. Deep incisions can result in increased bank cutting as the stream reestablishes a stable floodplain inside the channel walls. Karig (2001) described the eventual stabilization of a reach of Six Mile Creek over a 30 year period as the stream incised a meter deeper with a vegetated flood plain eventually established inside stable meander bends with decreased bank cutting.

The current problems with excessive sedimentation in Cayuga Lake are also a consequence of the elimination of the extensive wetlands that were originally at its southern end. Most of the other Finger Lakes have relatively more intact wetland complexes at their southern ends which filter out sediment from tributaries. Cayuga Inlet (Figure 1) appears to be the tributary with the most severe recent changes in channel morphology which is probably due to extensive channelization at its lower end in 1966. A field survey in 2000 identified Cayuga Inlet as the tributary with the most severe bank erosion in the southern Cayuga basin (Cayuga Lake Watershed Intermunicipal Organization, 2000) and this bank 
erosion has been exacerbated in the lower reach due to extensive channelization. Aerial photos of abandoned channels and field reconnaissance indicate that the present stream bottom above the most heavily channelized reach has incised about 1.5 meters below the pre-1966 channel bottom. The head cut that resulted from this channel incision has worked its way several kilometers upstream. Although this incision may be only the most recent cause of bank erosion in Cayuga Inlet, it has likely exacerbated the problem. As with the Six Mile Creek reach described by Karig (2001), it may be many years before this channel achieves stability as the stream gradually reestablishes a stable floodplain inside the confines of the channel walls.

\section{Conclusions}

Based on the use of the mixing model and uncertainty analysis, the contribution of bank erosion to sediment loads in six southern Cayuga Lake watersheds ranged from 8 to 76\%. Glacial deposits appear to be important sources of the high bank erosion found in the study area. Several of the watersheds with the highest proportions of bank erosion are those with the most extensive and actively eroding streamside glaciolacustrine deposits. Samples collected from most of the other watersheds indicated proportionally lower contributions of bank erosion compared with most streams in the southern Cayuga basin. Bank sediment sources appear to be much less important in streams in the region lacking extensive eroding streamside glaciolacustrine and glacial drift deposits. 


\section{References}

Ashmore P, 1993. Contemporary erosion of the Canadian landscape. Progress in Physical Geography 17:190-204.

Bent GC. 2000. Suspended Sediment Characteristics on the Housatonic River Basin, Western Massachusetts and Parts of Eastern NY and Northwestern Connecticut, 1994-96. USGS Water Resources Investigations Report 00-4059.

Bouldin, D. 2002. Unpublished data for Virgil Creek (1972-1974). Professor Emeritus, Cornell University, Dept of Crop and Soil Science.

Bottrill LJ, Walling DE, Leeks GJL. 2000. Using recent overbank deposits to investigate contemporary sediment sources in larger river basins. In Tracers in Geomorphology. Foster IDL (ed)., London UK: John Wiley and Sons; 369-386.

Brigham ME, McCollough CJ, Wilkinson P. 2001. Analysis of Suspended Sediment Concentrations and Radioisotope levels in the Wild Rice River Basin, Northwestern Minnesota, 1973-98. US Geological Survey, Water Resources Investigation Report 01-4192. Washington D.C.

Cadwell DH. 1986. Surficial Geologic Map of New York. New York State Museum-Geological Survey. Albany, NY. 
Cayuga Lake Watershed Intermunicipal Organization. 2000. Road and Streambank Inventory Project Report. Auburn, NY.

Cayuga Lake Watershed Intermunicipal Organization. 2002. Cayuga Lake Preliminary Watershed Characterization. Auburn, NY.

Collins Al, Walling DE. 2004. Documenting catchment suspended sediment sources; problems, approaches and prospects. Progress in Physical Geography. 28: 159-196.

Collins AL, Walling DE, Leeks GJL. 1997. Source type ascription for fluvial sediment based on a quantitative composite fingerprinting technique. Catena 29: 1-27.

Collins Al, Walling DE. 2004. Documenting catchment suspended sediment sources; problems, approaches and prospects. Progress in Physical Geography. 28: 159-196.

Crosby G, De Boer DH. 1995. Suspended sediment characteristics and drainage basin scale on the Canadian prairie. In International Association of Hydrological Sciences Publication, 226 : 6572.

Dobyns HF. 1981. From Fire to Flood: Historic Human Destruction of Sonoran Desert Riverine Oases. Socorro, New Mexico: Ballena Press.

Environmental Protection Agency (EPA). 1991. Genesee River Watershed Study; Special Studies, United States Geological Survey. EPA Great Lakes National Program Office. Chicago, Illinois. 
Fenneman NM 1938. Physiography of Eastern United States. New York: McGraw -Hill.

Fitzpatrick FA, Knox JC, Whitman HE. 1999. Effects of Historical Land-Cover Changes on Flooding and Sedimentation, North Fish Creek, Wisconsin. USGS Water Investigations Report 99-4083.

Foster IDL, Lees JA. 2000. Tracers in geomorphology: theory and applications in tracing fine particulate sediments. In Tracers in Geomorphology. Foster IDL (ed).: John Wiley and Sons: London UK; 3-20.

Froehlich W, Walling DE. 1997. The role of unmetalled roads as a sediment source in the fluvial systems of the Polich Flysch Carpathians. In International Association of Hydrological Sciences Publication, 245: 159-168.

Froelich W. Walling DE. 2005. Using environmental radionuclides to elucidate sediment sources within a small drainage basin in the Polish Flysch Carpathians. In International Association of Hydrological Sciences Publication, 291: 102-112.

Genesee/Finger Lakes Regional Planning Council. 2001. Cayuga Lake Watershed Restoration and Protection Plan. Rochester, N.Y.

Glasmann JR. 1997. Clay Minerology of Soils Exposed in Riverbank Cuts Below Big Cliff Reservoir, North Santiam River Drainage. Philomath, OR: Willamette Geological Service. 
Gordon RB. 1979. Denudation rate of central New England determined from estuarine sedimentation. American Journal of Science 279:632-642.

Hasholt P. 1988. On identification of sources of sediment transport in small basins with special reference to particulate phosphorus. International Association of Hydrological Sciences Publication, 226: 241-256.

Karig DE. 2001. Recent channel degradation in Six Mile Creek. In Environmental Research in the Cayuga Lake Watershed. Wagenet LP (ed)., Cornell University,: Center for the Environment: Ithaca, NY; 3-13.

Karig DE, Bloom AL, Bauer MR, Griffen SA. 1995. Recent Channel Degradation in Six Mile Creek. Unpublished report. Cornell University, Dept of Geological Sciences: Ithaca; NY.

Knox JC. 1977. Human impacts on Wisconsin stream channels. Annals of the Association of American Geographers 67:323-342.

Leopold LB. 1994. A View of the River. Cambridge, MA: Harvard University Press.

Matisoff G, Bonniwell EC, Whiting PJ. 2002. Soil erosion and sediment sources in an Ohio watershed using Beryllium ${ }^{-7}$, Cesium ${ }^{-137}$, and Lead ${ }^{-210}$. Journal of Environmental Quality 31:54-61.

Michels WC. 1957. Electrical Measurements and Their Applications. Princeton, NJ: D. Van Norstrand. Morgan, M. G., M. Henrion. 1990. Uncertainty : a guide to dealing with uncertainty in quantitative risk and policy analysis. Cambridge ; New York, Cambridge University Press. 
Nagle GN, Ritchie J. 1999. The use of tracers to study sediment sources in three streams in northeastern Oregon. Physical Geography 20:348-366.

Nagle GN, Ritchie J. 2004. Wheat field erosion rates and channel bottom sediment sources in an intensively cropped northeastern Oregon drainage basin. Land Degradation and Development 14:1-12.

Nagle GN, Lassoie JP, and Fahey TJ. 2000. The use of caesium-137 to estimate agricultural erosion on steep slopes in a tropical watershed. Hydrological Processes 14:957-969.

National Research Council 1992 Restoration of Aquatic Ecosystems. National Academy Press, Washington. D.C.

National Research Council 2000 Watershed Management for Potable Water Supply. Washington DC: National Academy Press.

New York State Department of Environmental Conservation. 2002. Unpublished data from Beerston gauging station, West Branch Delaware River. Albany, New York.

Odgaard AJ. 1987. Streambank erosion along two rivers in Iowa. Water Resources Research 23:12251236.

Olley JM, Murray AS, Mackenzie DH, Edwards K. 1993. Identifying sediment sources in a gullied catchment using natural and anthropogenic radioactivity. Water Resources Research 29:10371043. 
Parker M, Wood FJ, Smith BH, Elder RG. 1985. Erosional downcutting in lower order riparian ecosystems: have historical changes been caused by the removal of beaver? In Riparian Ecosystems and Their Management: Reconciling Conflicting Uses, First North American Riparian Conference. 325-331 April 16-18, 1985 Tucson AZ.: USDA Forest Service General Technical Report RM-120. Ft. Collins, CO.

Peart MR, Walling DE. 1988. Techniques for establishing suspended sediment sources in two drainage basins in Devon, UK: A comparative assessment. In International Association of Hydrological Sciences Publication, 174: 269-279.

Peart MR, Walling DE. 1986. Fingerprinting sediment sources: The example of a drainage basin in Devon. International Association of Hydrological Sciences Publication, 173: 41-55.

Phillips JD. 1991. Fluvial sediment budgets in the North Carolina piedmont. Geomorphology 4:231-241.

Porter KS. 1975. Nitrogen and Phosphorus: Food Production, Waste and the Environment. Ann Arbor, MI: Ann Arbor Science Publishers.

Rich JL 1934. Glacial Geology of the Catskills. Albany, NY. New York State Museum Bulletin No. 299.

Sekely AC, Mulla DJ, Bauer DW. 2002. Streambank slumping and its contribution to the phosphorus and suspended sediment loads of the Blue Earth River, Minnesota. Journal of Soil and Water Conservation 57:243-250. 
Slattery MC, Burt TC, Walden J. 1995. The application of mineral magnetic measurements to quantify within-storm variations in suspended sediment sources. In International Association of Hydrological Sciences Publication, 229: 143-151

Stone M, Sauderson HC. 1996. Regional patterns of sediment yield in the Laurentian Great Lakes Basin. In International Association of Hydrological Sciences Publication, 236: 125-131

Symander W, Strunk N. 1992. Determining the source of suspended particulate material. In International Association of Hydrological Sciences Publication, 209: 177-185.:

Trimble SW 1983. A sediment budget for Coon Creek Basin in the Driftless Area, Wisconsin, 18531977. American Journal of Science 283:545-574.

Trimble SW, Crosson.P. 2000. U.S. Soil erosion rates: Myth and reality. Science 289:248-250.

US Geological Survey. 2002. Water Resources Data, New York: Water Year 2001. Vol 3, Western New York. Water Data Report NY-01-3.

US Geological Survey. 2001. Water Resources Data, New York: Water Year 2000. Vol 3, Western New York. Water Data Report NY-00-3.

USDA, Soil Conservation Service. 1975. Erosion, Sediment and Related Salt Problems and Treatment Opportunities. Golden, CO. 
Wallbrink PJ, Murray AS. 1996. Distribution and variability of Be-7 in soils under different surface cover conditions and its potential for describing soil redistribution processes. Water Resources Research 32:467-476.

Wallbrink PJ, Olley JM, Murray AS, Olive LJ. 1996. The contribution of subsoil to sediment yield in the Murrumbridgee River basin, New South Wales, Australia. In International Association of Hydrological Sciences Publication, 236: 347-355.

Wallbrink PJ, Murray AS, Olley JM. 1998. Determining sources and residence time of suspended sediment in the Murrumbidgee River, New South Wales, Australia, using fallout $\mathrm{Cs}^{-137}$ and $\mathrm{Pb}^{-210}$. Water Resources Research 34:879-887.

Walling DE, 2004 Using environmental radionuclides as tracers in sediment budget investigations. In International Association of Hydrological Sciences Publication, 283: 57-78.

Walling DE, Bradley SB. 1990. Some applications of caesium-137 measurements in the study of erosion, transport and deposition.:, In International Association of Hydrological Sciences Publication, 189: 179-203.

Walling DE, Woodward JC, Nicholas AP. 1993. A multi-parameter approach to fingerprinting suspended -sediment sources. In International Association of Hydrological Sciences Publication, 215: $329-338$ 
Whitney GG. 1994. From Coastal Wilderness to Fruited Plain: A History of Environmental Change in Temperate North America, 1500 to the Present. Cambridge, UK Cambridge University Press,.

Williams KF., Reed LA. 1972. Appraisal of Stream Sedimentation in the Susquehanna River Basin. U.S. Geological Survey Water Supply Paper 1532-F.

Yager R 2001. Estimating sedimentation rates in Cayuga Lake, New York from sediment profiles of Cs-137 and Pb-210 activity. In Environmental Research in the Cayuga Lake Watershed. Wagenet LP (ed). Cornell University, Center for the Environment. Ithaca, NY: 78-102

Youngberg CT, Klingeman PC . 1971. Hills Creek Reservoir Turbidity Study. Corvallis, OR Water Resources Research Institute, Oregon State University,.

Zhang, X and Y Zhang. 1995. Use of Caesium-137 to investigate Sediment Sources in the HekouzhenLongmen Basin of the Middle yellow River, China. In Sediment and Water Quality in River Catchments. Foster IDL (ed)., London UK: John Wiley and Sons; 353-362.

Zhang X, DE Walling, TA Quine and A. Wen. 1997. Use of reservoir deposits and Cs-137 measurements to investigate the erosional response of a small drainage basin of the rolling Loess Plateau region of China. Land Degradation and Development 8: 1-16. 


\section{List of Figures}

Figure 1. Location of the Cayuga and Catskill watersheds studied for bank erosion and locations of other sediment yield studies in New York State.

Figure 2. Percentage of sediment load from surface erosion. Panel A shows streams with relatively extensive or moderate glaciolacustrine deposits, and Panel B shows streams with limited glaciolacustrine deposits. The range of values for each stream represents the results of the Monte Carlo analysis, with the median shown with a plus symbol (+), the 25th and 75th quartiles shown by the box, and the maximum and minimum values shown with the line. Note the maximum and minimum values and sometimes other quantiles are zero and $100 \%$ because of the large range of predictions due to the large number of iterations used in the Monte Carlo analysis $(100,000)$.

\section{List of tables}

Table 1. Mean Cs-137 (mBq g ${ }^{-1}$ ) levels for stream sediment and potential source materials. Each surface sample was a composit of 8 separate cores distributed across the study slopes.

Table 2. Concentration of Cs-137 (mBq g-1 ) in streams and percentage of sediment from cultivated soils based on quantitative uncertainty analysis.

Table 3. Suspended sediment yield studies for central New York watersheds (in tons $\mathrm{km}^{-2} \mathrm{yr}^{-1}$ ). 
Figure 1. Location of the Cayuga and Catskill watersheds studied for bank erosion and locations of other sediment yield studies in New York State.

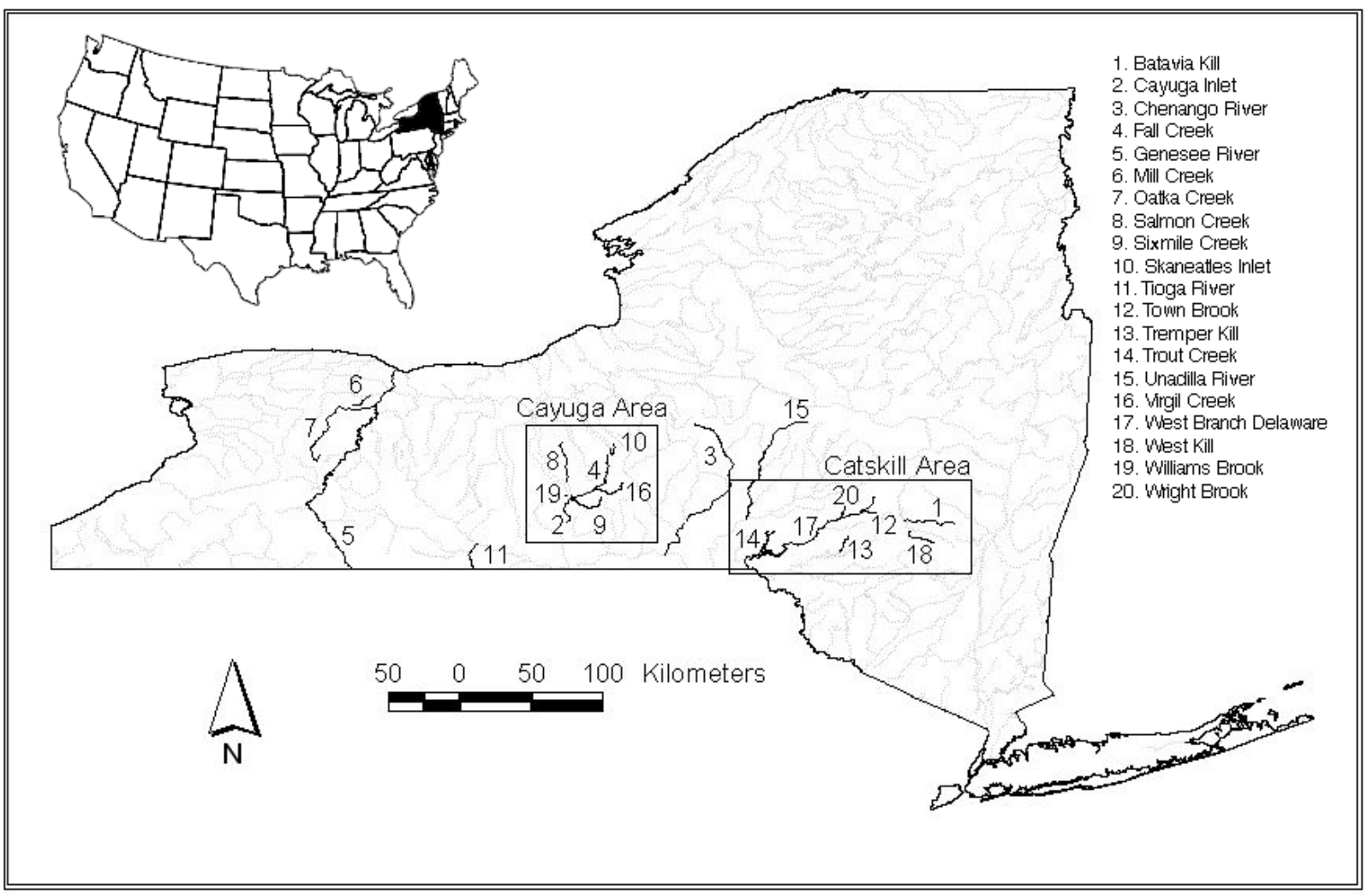


Figure 2. Percentage of sediment load from surface erosion. Panel A shows streams with relatively extensive or moderate glaciolacustrine deposits, and Panel B shows streams with limited glaciolacustrine deposits. The range of values for each stream represents the results of the Monte Carlo analysis, with the median shown with a plus symbol (+), the 25th and 75th quartiles shown by the box, and the maximum and minimum values shown with the line. Note the maximum and minimum values and sometimes other quantiles are zero and $100 \%$ because of the large range of predictions due to the large number of iterations used in the Monte Carlo analysis $(100,000)$.
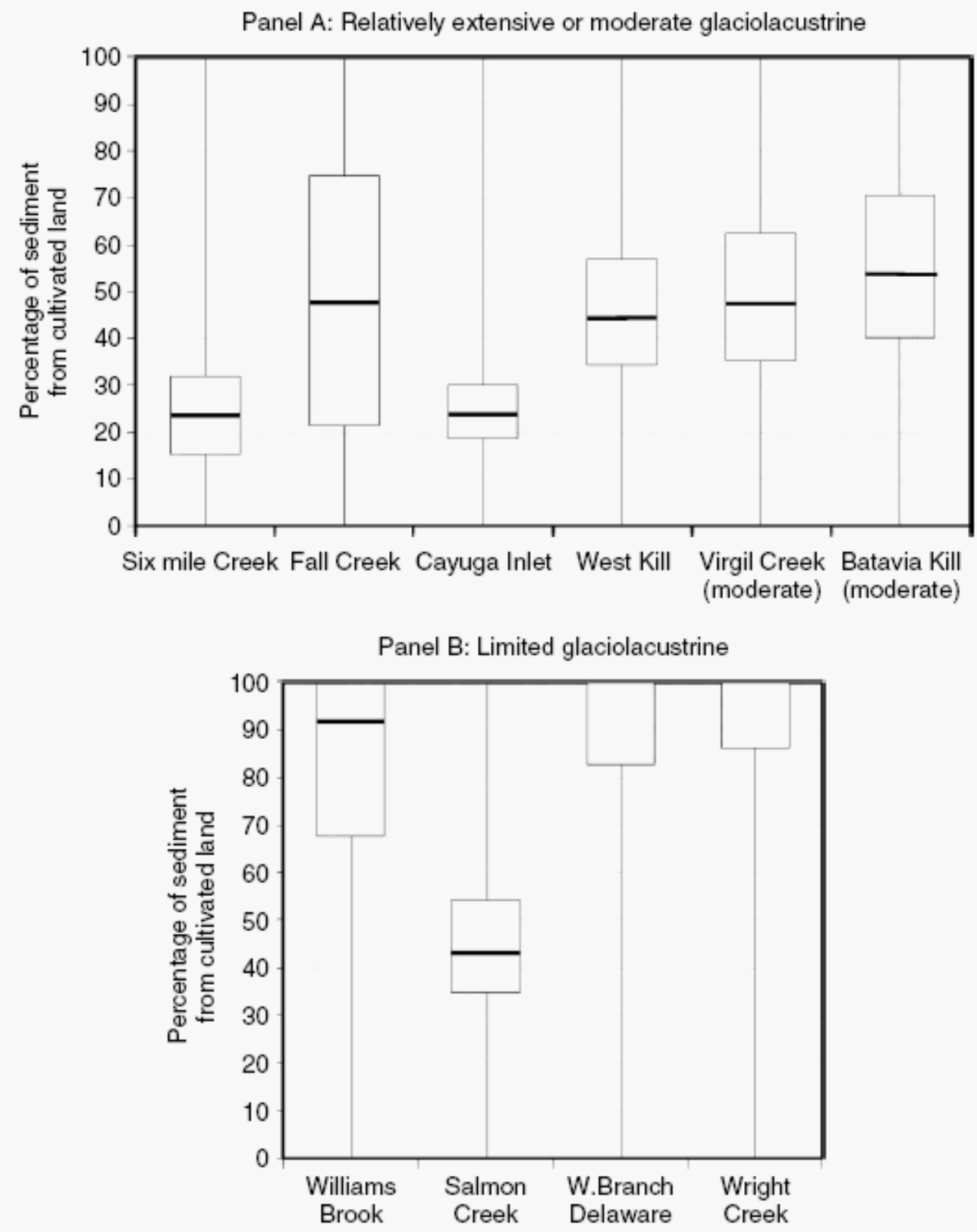
Table 1. Mean Cs-137 (mBq g ${ }^{-1}$ ) levels for stream sediment and potential source materials. Each surface sample was a composit of 8 separate cores distributed across the study slopes.

\begin{tabular}{|c|c|c|c|c|c|}
\hline & $\begin{array}{c}\text { Bank } \\
\text { material }\end{array}$ & $\begin{array}{c}\text { Cultivated } \\
\text { surface soil } \\
(\mathbf{n = 2 6 )}\end{array}$ & $\begin{array}{c}\text { Pasture } \\
\text { surface soi }\end{array}$ & $\begin{array}{c}\text { Forest } \\
\text { surface soil }\end{array}$ & $\begin{array}{c}\text { Stream } \\
\text { Sediment* }\end{array}$ \\
\hline $\begin{array}{c}\text { Cs-137 } \\
\left(\mathrm{mBq} \mathrm{g}^{-1}\right)\end{array}$ & 0.4 & 11.5 & $\mathbf{( n )}$ & 23.7 & 24.1 \\
\hline $\begin{array}{c}\text { Range } \\
\left(\mathrm{mBq}^{-1}\right)\end{array}$ & $0-5.3$ & $7.7-16.36$ & $20.1-27.7$ & $19.6-28.5$ & 4.8 \\
\hline
\end{tabular}


Table 2. Concentration of Cs-137 ( $\left.\mathrm{mBq} \mathrm{g}^{-1}\right)$ in streams and percentage of sediment from cultivated soils based on quantitative uncertainty analysis.

\begin{tabular}{|c|c|c|c|c|c|c|c|}
\hline \multirow[t]{3}{*}{ Stream name } & \multirow{3}{*}{$\begin{array}{l}\text { Region and } \\
\text { physiographic } \\
\text { setting }\end{array}$} & \multicolumn{2}{|c|}{$\begin{array}{l}\text { Cs-137 in stream } \\
\text { Sediment }\left(\mathbf{m B q} \mathbf{~ g}^{-1}\right)\end{array}$} & \multicolumn{3}{|c|}{ Percentage of sediment load from surface erosion* } & \multirow{2}{*}{$\begin{array}{c}\begin{array}{c}\text { Percentage of } \\
\text { sediment load from } \\
\text { bank erosion }\end{array} \\
\text { Median } \\
\end{array}$} \\
\hline & & & & Low & Median & High & \\
\hline & & Mean & Range & (20th percentile) & (50th percentile) & (80th percentile) & (50th percentile) \\
\hline Six Mile & $\begin{array}{c}\text { Southern Cayuga } \\
\text { Lake basin }\end{array}$ & 2.7 & $0-1.2$ & 13 & 24 & 34 & 76 \\
\hline Fall Creek & $\begin{array}{l}\text { Southern Cayuga } \\
\text { Lake basin } \\
\\
\text { Relatively } \\
\text { extensive } \\
\text { glaciolacustrine }\end{array}$ & $\begin{array}{c}5.4 \\
(n=10)\end{array}$ & $1.5-10.5$ & 16 & 48 & 81 & 52 \\
\hline Cayuga Inlet & \begin{tabular}{|} 
Southern Cayuga \\
Lake basin \\
Relatively \\
extensive \\
glaciolacustrine
\end{tabular} & $\begin{array}{c}2.9 \\
(n=9)\end{array}$ & $2.3-3.8$ & 17 & 24 & 32 & 76 \\
\hline Virgil & $\begin{array}{c}\text { Southern Cayuga } \\
\text { Lake basin }\end{array}$ & $\begin{array}{c}5.5 \\
(n=15)\end{array}$ & $2.5-8.6$ & 32 & 47 & 67 & 53 \\
\hline
\end{tabular}




\begin{tabular}{|c|c|c|c|c|c|c|c|}
\hline & $\begin{array}{c}\text { Moderate } \\
\text { glaciolacustrine }\end{array}$ & & & & & & \\
\hline \multirow{2}{*}{$\begin{array}{c}\text { Williams } \\
\text { Brook }\end{array}$} & Southern Cayuga & \multirow{2}{*}{$\begin{array}{l}13.8 \\
(\mathrm{n}=4)\end{array}$} & \multirow[t]{2}{*}{$7.5-29.4$} & 63 & 92 & 10 & 8 \\
\hline & $\begin{array}{l}\text { Limited } \\
\text { glaciolacustrine }\end{array}$ & & & & & & \\
\hline \multirow[t]{2}{*}{ Salmon Creek } & Southern Cayuga & \multirow{2}{*}{$\begin{array}{c}5.4 \\
(n=12)\end{array}$} & \multirow[t]{2}{*}{$3.9-7.2$} & 33 & 43 & 58 & 57 \\
\hline & $\begin{array}{l}\text { Lake basin } \\
\text { Limited } \\
\text { glaciolacustrine }\end{array}$ & & & & & & \\
\hline \multirow{3}{*}{$\begin{array}{c}\text { Skaneateles } \\
\text { Inlet }\end{array}$} & Finger Lakes & \multirow{3}{*}{$\begin{array}{c}8.8 \\
(\mathrm{n}=2)\end{array}$} & \multirow[t]{3}{*}{$8.59-9.04$} & na & 75 & na & 25 \\
\hline & \multirow{2}{*}{$\begin{array}{l}\text { Limited } \\
\text { glaciolacustrine }\end{array}$} & & & & & & \\
\hline & & & & & & & \\
\hline \multirow{2}{*}{$\begin{array}{l}\text { West Branch } \\
\text { Delaware }\end{array}$} & Catskills & \multirow{2}{*}{$\begin{array}{c}12.9 \\
(\mathrm{n}=5)\end{array}$} & \multirow[t]{2}{*}{$9.44-20.0$} & 79 & 100 & 100 & $\mathbf{0}$ \\
\hline & $\begin{array}{c}\text { Limited } \\
\text { glaciolacustrine }\end{array}$ & & & & & & \\
\hline \multirow{2}{*}{$\begin{array}{l}\text { Trout } \\
\text { Creek }\end{array}$} & Catskills & \multirow{2}{*}{$\begin{array}{c}15.3 \\
(\mathrm{n}=3)\end{array}$} & \multirow[t]{2}{*}{$13.7-17.6$} & na & 100 & na & $\mathbf{0}$ \\
\hline & $\begin{array}{l}\text { Limited } \\
\text { glaciolacustrine }\end{array}$ & & & & & & \\
\hline Wright & Catskills & $\begin{array}{c}12.5 \\
(n=4)\end{array}$ & $9.6-15.8$ & 81 & 100 & 10 & $\mathbf{0}$ \\
\hline
\end{tabular}




\begin{tabular}{|c|c|c|c|c|c|c|c|}
\hline & $\begin{array}{c}\text { Limited } \\
\text { glaciolacustrine }\end{array}$ & & & & & & \\
\hline Town Brook & $\begin{array}{c}\text { Catskills } \\
\text { Limited } \\
\text { glaciolacustrine }\end{array}$ & $\begin{array}{c}8.4 \\
(n=3)\end{array}$ & $6.43-10.3$ & na & 73 & na & 27 \\
\hline $\begin{array}{c}\text { Little } \\
\text { Delaware }\end{array}$ & $\begin{array}{c}\text { Catskills } \\
\text { Limited } \\
\text { glaciolacustrine }\end{array}$ & $\begin{array}{c}8.7 \\
(n=1)\end{array}$ & 8.7 & na & 74 & na & 26 \\
\hline Tremper Kill & $\begin{array}{c}\text { Catskills } \\
\text { Limited } \\
\text { glaciolacustrine }\end{array}$ & $\begin{array}{c}9.9 \\
(\mathrm{n}=1)\end{array}$ & 9.9 & na & 85 & na & 15 \\
\hline Batavia Kill & $\begin{array}{c}\text { Catskills } \\
\text { Moderate } \\
\text { glaciolacustine }\end{array}$ & $\begin{array}{c}6.5 \\
(n=5)\end{array}$ & 4.06-8.9 & 37 & 54 & 76 & 46 \\
\hline West Kill & $\begin{array}{c}\text { Catskills } \\
\text { Relatively } \\
\text { extensive } \\
\text { glaciolacustine }\end{array}$ & $\begin{array}{c}5.1 \\
(n=4)\end{array}$ & 2.3-6.9 & 32 & 44 & 61 & 56 \\
\hline
\end{tabular}

*Because quantitative uncertaintly analysis was used to estimate sediment sources, the estimate is in the form of a distribution of values. The specified percentiles of this distribution are shown for each stream. Note that for streams with fewer than 4 samples, only the 50th percentile result is reported. 
Table 3. Suspended sediment yield studies for central New York watersheds (in tons $\mathrm{km}^{-2} \mathrm{yr}^{-1}$ ).

\begin{tabular}{|c|c|c|}
\hline $\begin{array}{c}\text { Source } \\
\text { (year sampled) }\end{array}$ & Location & Tons $\mathrm{km}^{-2} \mathrm{yr}^{-1}$ \\
\hline Leopold, 1994 & $\begin{array}{c}\text { N.E. US } \\
\text { Drawn from variety of studies in this region }\end{array}$ & 87 \\
\hline $\begin{array}{l}\text { Fall Creek Study, } \\
\text { Porter, 1975 } \\
(1972-1974)\end{array}$ & $\begin{array}{c}\text { Fall Creek } \\
\text { Data from Forest Home site }\end{array}$ & 42 \\
\hline \multirow[t]{2}{*}{$\begin{array}{c}\text { Bouldin, 2002 } \\
(5 / 74-8 / 75)\end{array}$} & $\begin{array}{c}\text { Fall Creek } \\
\text { Data from Freeville site }\end{array}$ & 23 \\
\hline & $\begin{array}{c}\text { Virgil Creek } \\
\text { Data from Freeville site }\end{array}$ & 57 \\
\hline $\begin{array}{l}\text { USGS, 2000-2001 } \\
2000 \text { water year }\end{array}$ & Six Mile Creek & 203 \\
\hline 2001 water year & Six Mile Creek & 138 \\
\hline \multirow[t]{4}{*}{$\begin{array}{c}\text { EPA Genesee Basin } \\
\text { Study, 1991 } \\
(1975-77)\end{array}$} & Genesee at Mt Morris & 204 \\
\hline & Oatka Creek at Warsaw & 20 \\
\hline & Oatka Creek at Garbutt & 6 \\
\hline & Mill Creek & 119 \\
\hline $\begin{array}{l}\text { NY State DEC } \\
(1991-2001)\end{array}$ & West Branch Delaware at Beerston & 24 \\
\hline $\begin{array}{l}\text { NY State DEC } \\
(1999-2000)\end{array}$ & $\begin{array}{c}\text { Towne Brooke } \\
\text { (upper West Branch Delaware) }\end{array}$ & 67 \\
\hline \multirow[t]{5}{*}{$\begin{array}{l}\text { Williams and Reed, } \\
1972\end{array}$} & $\begin{array}{c}\text { Tioga River } \\
\text { (western Susquehanna basin ) }\end{array}$ & 66 \\
\hline & $\begin{array}{c}\text { Chemung } \\
\text { (western Susquehanna basin ) }\end{array}$ & 53 \\
\hline & $\begin{array}{c}\text { Canisteo River } \\
\text { (western Susquehanna basin ) }\end{array}$ & 154 \\
\hline & $\begin{array}{c}\text { Unadilla River } \\
\text { (eastern Susquehanna basin ) }\end{array}$ & 14 \\
\hline & $\begin{array}{c}\text { Chenango River } \\
\text { (eastern Susquehanna basin ) }\end{array}$ & 17 \\
\hline
\end{tabular}


